\title{
Relationships between bird morphology and prey selection in two sympatric Great Cormorant Phalacrocorax carbo subspecies during winter
}

Frédéric Fonteneau · Jean-Marc Paillisson · Loïc Marion

Frédéric Fonteneau · Jean-Marc Paillisson · Loïc Marion

UMR CNRS Ecobio, Université de Rennes 1, Campus Beaulieu, Avenue du Général Leclerc, 35042 Rennes cedex, France

e-mail: frederic.fonteneau@gmail.com 
Fonteneau et al. - 2009 - Relationships between bird morphology and prey selection in two sympatric Great Cormorant Phalacrocorax carbo subspecies during winter.

\begin{abstract}
Variation in bird morphology (notably sex size dimorphism) has been suggested to contribute to differences in food use between individuals. We explore the hypothesis of food partitioning (diet overlap and prey size selection) in two sympatric subspecies of the Great Cormorant Phalacrocorax carbo with respect to bird morphology (subspecies and sex) in inland French waters. These areas represent a recent and increasing contact zone used as a common non-territorial winter feeding area by the continental $P$. c. sinensis and the marine $P$. c. carbo subspecies. A high dietary overlap between subspecies and sexes was found at the major sites studied. Prey size selection was found to be site-specific and generally related to a gradient of structural size and body mass (male $P$. c . carbo $>$ male $P$. c . sinensis $>$ female $P$. c. carbo $>$ female P. c. sinensis). With respect to bird morphology, differences in prey size consumed by Great Cormorants were more pronounced between sexes in freshwater habitats than between subspecies. This was reinforced by the fact that $P$. c. carbo birds entering inland areas were smaller than birds on the coast. These results also suggest that bird morphology is an important determinant of dietary differences. Our study demonstrated that $P$. c c carbo is an efficient generalist forager in continental areas, and food partitioning in type and size of prey between the two subspecies is low.
\end{abstract}

Keywords: Diet overlap $\cdot$ feeding ecology $\cdot$ prey size selection $\cdot$ sexual dimorphism 
Fonteneau et al. - 2009 - Relationships between bird morphology and prey selection in two sympatric Great Cormorant Phalacrocorax carbo subspecies during winter.

\section{Introduction}

Different strategies are developed by animals to exploit and to partition food resources between individuals, especially when resources are fluctuating (e.g. Marti et al. 1993, Chesson \& Huntly 1997, Bolnick \& Doebeli 2003, Garcia \& Arroyo 2005). Between individuals of the same species, food niche partitioning is not the rule, particularly in colonial species, except when they are territorial feeders (Marion 1989) or when differences in resource requirements or behaviour are related to age or sex size dimorphism (Goss-Custard \& Durell 1983, Lewis et al. 2006, Slagsvold \& Sonerud 2007). Differences in body size (reflecting in particular sex size dimorphism) may contribute to differences in food use (e.g. Slatkin 1984, Hedrick \& Temeles 1989, Shine 1989, Bolnick \& Doebeli 2003, Zalewski 2007). In birds, the presumed ecological importance of size dimorphism has been studied with reference to feeding ecology, including type and size of prey (Koffijberg \& van Eerden 1995, Slagsvold \& Sonerud 2007), feeding areas (Weimerskirch et al. 1993, 2006, Shaffer et al. 2001) and foraging strategies (Ydenberg \& Forbes 1991, Wanless et al. 1995, González-Solís et al. 2000). In most cases, studies on birds are carried out during the breeding season, when particular physiological, behavioural and energetic constraints (e.g. chick provisioning, interactions with partner) occur and govern food exploitation. These issues are rarely addressed outside the reproductive period, when individuals forage only for themselves.

In the present study, we address the question of food resource use in the Great Cormorant Phalacrocorax carbo with respect to bird morphology. The Great Cormorant is a large colonial waterbird species exhibiting size dimorphism between sexes and also between subspecies. It is an opportunistic, non-territorial predator which feeds almost exclusively on fish (van Eerden et al. 1995, Keller et al. 2003). The only published data related to food partitioning in the Great Cormorant came from a study carried out in The Netherlands (Koffijberg \& van Eerden 1995). In this study, the authors did not find differences in diet composition between sexes, but suggested that there was a positive link between sexual size dimorphism of birds (males > females) and prey size in some fish species. However, data consisted of a limited number of birds collected throughout the year (i.e. including breeders and wintering birds).

The two subspecies usually found in Europe are P. c. sinensis and P. c. carbo (Cramp \& Simmons 1977, del Hoyo et al. 1992), although recent molecular investigations have shown a new marine subspecies, P. c. norvegicus, that occurs mainly in Norway (Marion \& Le Gentil 
Fonteneau et al. - 2009 - Relationships between bird morphology and prey selection in two sympatric Great Cormorant Phalacrocorax carbo subspecies during winter.

2006). Traditionally, P. c. sinensis inhabits various freshwater habitats across continental Europe, mainly in Denmark and The Netherlands, and P. c. carbo, the marine subspecies, breeds on the coasts of the British Isles, France, Norway and Iceland (Cramp \& Simmons 1977, van Eerden \& Gregersen 1995, Marion 1995, Marion \& Le Gentil 2006). Following near extinction in the mid-20th century, the $P$. c . sinensis subspecies has benefited from protection from human persecution (notably by the European Community Directive on the Conservation of Wild Birds in 1979), anthropogenic eutrophication of coastal and freshwater systems and the resulting increase in fish abundance (van Eerden \& Gregersen 1995, van Dam \& Asbirk 1997, Suter 1997). It has increased from about 5300 breeding pairs in 1970 to 200000 pairs in the late 1990s (van Dam \& Asbirk 1997, Marion 1997). This spectacular increase has led to a strong geographical extension of the wintering population in Europe (about 560000 individuals in 2003; Marion \& Parz-Gollner 2009), particularly in France with up to 99000 wintering Great Cormorants in 2007 (Marion 2007), where the two subspecies P. c. carbo and P. c. sinensis meet. Moreover, while there was still a strong ecological and geographical segregation between these subspecies during both breeding and wintering before 1992, with sympatric areas limited to brackish waters in estuaries during wintering (Marion 1983), an increasing overlap occurred in northwest France in the 1990s (Marion 1994, 1995), which nowadays extends to a large proportion of the country (Fonteneau \& Marion 2009). This significant overlap is due to the fact that the marine $P$. c. carbo subspecies invaded inland waters, resulting in mixed winter roosts and subsequently mixed breeding colonies in Western France (Marion \& Le Gentil 2006). A similar pattern has been reported recently in the UK (Goostrey et al. 1998, Winney et al. 2001, Newson et al. 2004). In this context, this raises the question of the niche the $P$. c c carbo subspecies can occupy in freshwater habitats. Indeed, the marine subspecies has evolved in rocky marine coasts where individuals have to hunt marine fish in a relatively harsh aquatic environment. These conditions are considered to explain the higher body size of $P$. c . carbo compared to that of $P$. $c$. sinensis, which has evolved in wetlands.

This situation offers us the opportunity to study niche partitioning of previously allopatric subspecies that now show increasing overlap during winter. Based on a large sample of wintering Great Cormorants shot in France in the same feeding areas (see below), we examined the extent of size dimorphism in four bird groups (two subspecies $x$ two sexes), and determined whether differences in food niche in terms of type (trophic overlap) and size of prey (variable responses to prey species) existed between the Great Cormorant groups. 
Fonteneau et al. - 2009 - Relationships between bird morphology and prey selection in two sympatric Great Cormorant Phalacrocorax carbo subspecies during winter.

\section{Methods}

\section{Collection of birds}

The spectacular increase in the European continental population of Great Cormorant and the reputation of the species for consuming large amounts of fish have resulted in the species acquiring a negative public image, resulting in conflicts with fisheries and aquacultures (e.g. Kirby et al. 1996, Carss 2003). Management actions, including widespread culling, have been taken in several countries to reduce these conflicts, notably in France, where culling reached up to 32000 Great Cormorants in 2006/2007 (Marion 2007).

In the present study, all the Great Cormorants studied were shot (under Ministry of the Environment licences) in France (mainly in the western half), in feeding areas during the daytime period or in night roosts in 28 'départements' (administrative districts) during the winters of 2001/2002 to 2006/2007 (Fig. 1). The Great Cormorants collected came from a variety of aquatic habitats (mainly large and medium-sized rivers, but also ponds, some inland marshes and reservoirs and to a lesser degree brackish and estuarine areas), where birds mainly feed solitarily. Birds were frozen (at $-20^{\circ} \mathrm{C}$ ) immediately after collection. To facilitate data analysis, all localities $(1-7$, mean $\pm s d=2.9 \pm 1.7)$ within a 'département' (hereafter called a 'site') were grouped, as they were always neighbouring.

\section{Morphology of Great Cormorants}

Recently, Newson et al. (2004) found that the shape of the gular pouch, an area of bare flesh on the face, is a useful characteristic for assigning individuals to subspecies. Birds with gular pouch angles $\leq 65^{\circ}$ (measured after thawing) were classified into the $P$. c. carbo subspecies, and those with angles $\geq 73^{\circ}$ or more to $P$. c . sinensis. Great Cormorants with gular pouch angles of $66-72^{\circ}$ cannot be reliably differentiated using gular angle alone (Newson et al. 2004). There was no correlation between the gular pouch angle and the body size of birds for each Great Cormorant group (Pearson correlation, $\mathrm{P}>0.05$ ), therefore there was no bias in the body size distribution of both subspecies when discarding birds with a gular pouch ranging from $66^{\circ}$ to $72^{\circ}$. P. c. norvegicus, which only represented $6.9 \%$ of wintering birds in the area studied, and whose gular pouch angles are included in those of P. c. carbo (J. Le Gentil \& L. Marion unpubl. data), was not distinguished from the latter and we henceforth use the name of $P$. c c carbo for both marine subspecies. Birds were also sexed by gonad 
Fonteneau et al. - 2009 - Relationships between bird morphology and prey selection in two sympatric Great Cormorant Phalacrocorax carbo subspecies during winter.

examination and aged as immature or adult by plumage characteristics (Cramp \& Simmons 1977).

Several morphological measurements were taken: body mass (without stomach content $\pm 1 \mathrm{~g}$ ), bill-length (from bill tip to exposed culmen $\pm 0.1 \mathrm{~mm}$ ), bill-depth and bill-width (measured perpendicular to and including the lower mandible and exposed culmen $\pm 0.1 \mathrm{~mm}$ ), tarsus-length (length of metatarsus from the anterior side of the ankle joint to the distal end of the metatarsus) and wing-length (from carpal joint to top of wing $\pm 1 \mathrm{~mm}$ ).

\section{Diet analysis}

In the present study, the diet of birds identified to subspecies was reported. The diet was analysed from stomach contents and based on undigested prey, which represent the last prey consumed and thus were representative of the site where birds were shot. The body length of prey (from the tip of the closed mouth to the centre of the tail fork) was measured to the nearest millimetre for fresh fish or accurately estimated using relationships between other morphological measurements when fish were partially digested (Froese \& Pauly 2007). Total identified fish were used to calculate a symmetrical overlap index (Pianka 1974) within bird groups (subspecies and sexes) using: Ov $=\Sigma p i q i /\left(\Sigma p i^{2} . \Sigma q i^{2}\right)^{1 / 2}$, where $p i$ and $q i$ are the proportion of species $i$, relative to the total number of species in the diet of bird groups. This index ranges from 0 to 1 (total overlap). Because Great Cormorants were collected in a variety of aquatic systems, the overlap index was computed at the site level, and only for the seven dominant sites ( $\geq 10$ Great Cormorants with diet in each bird group).

\section{Data analysis}

Normality and homoscedasticity of Great Cormorant and fish data were tested using Kolmogorov-Smirnov and Bartlett's tests respectively before analyses. Differences in body size across bird groups were tested with multivariate analysis of variance (MANOVA and Wilks' $\lambda$ statistic). Post-hoc univariate $F$-tests (Tukey procedure) were used to perform comparisons between bird groups. There was no difference in body size between immature and adult Great Cormorants in each bird group (subspecies x sex, Student's $t$-tests, $\mathrm{P}>0.05$ ); therefore, age groups were pooled in the analyses. A series of preliminary two-way ANOVAs was conducted to study differences in the body length of each fish species between Great Cormorant groups (i.e. subspecies or sex) and sites supporting similar bird groups. As the interaction group $\mathrm{x}$ site was significant in all analyses $(\mathrm{P}<0.05)$, the effect of group was 
Fonteneau et al. - 2009 - Relationships between bird morphology and prey selection in two sympatric Great Cormorant Phalacrocorax carbo subspecies during winter.

examined separately for each site (one-way ANOVA or Student's $t$-test). Statistical tests were performed using SYSTAT (SPSS Inc. 1998, version 10.0).

\section{Results}

\section{Bird groups and morphological features}

Based on the gular pouch, 1227 of a total of 1509 Great Cormorants collected during the winters of $2001 / 2002$ to $2006 / 2007$ were identified to subspecies (n $=420$ for P. c. carbo and $\mathrm{n}=807$ for $P$. c. sinensis). P. c. sinensis occurred at all sites; $P$. c. carbo was found at almost all sites (25 out of a total of 28 sites; Fig. 1). The relative abundance of the two subspecies varied between major sites (i.e. sites with $\geq 20$ birds assigned to subspecies; Fig. 1). Generally, continental sites supported a majority of birds of the P. c. sinensis subspecies, but the $P$. c. carbo subspecies was also well-represented at all sites (16.7-67.6\%). Males represented $62.1 \%$ and $47.3 \%$ of the total number of birds in $P$. c. carbo and P. c. sinensis subspecies, respectively (Table 1).

Great Cormorants of the four groups (subspecies and sexes) were arranged into a continuum of structural size (males of $P$. c c carbo $>$ males of $P$. $c$. sinensis $>$ females of P. c. carbo $>$ females of $P$. c. sinensis). Significant differences were found in all structural variables (bill-length, bill-depth, bill-width, tarsus-length and wing-length) between bird groups. The overall F-test was significant (Wilks' $\lambda=0.255, F_{15,3366}=143.2, P<0.001$ ), as were all post-hoc univariate $F$-tests $(P<0.05)$. The bill-length and bill-depth were larger in males than in females in the two subspecies $(+9.5 \%$ and $+10.9 \%$ for the bill-length, $+9.9 \%$ and $+11.3 \%$ for the bill-depth in P. c. carbo and P. c. sinensis subspecies, respectively; Table 1). Differences also occurred in the other structural characteristics between sexes in both subspecies, but to a lesser degree (from +4.2 to $+7.8 \%$ for males; Table 1 ). For each morphological feature, birds of the P. c. carbo subspecies were larger than birds of the $P$. c. sinensis subspecies for each separate sex, but differences were more subtle than the size dimorphism found within each subspecies (from +1.0 to $+5.9 \%$ compared to +4.2 to $+11.3 \%$; Table 1). Differences also occurred in body mass between bird groups (overall ANOVA, $\left.F_{3,1223}=287.0, P<0.001\right)$, with a similar gradient in bird groups to that for the structural features. Males were heavier than females $(+17.1 \%$ and $+20.9 \%$ for $P$. c c carbo and 
Fonteneau et al. - 2009 - Relationships between bird morphology and prey selection in two sympatric Great Cormorant Phalacrocorax carbo subspecies during winter.

P. c. sinensis, respectively) and birds of $P$. c. carbo were heavier than birds of $P$. c. sinensis $(+7.4 \%$ and $+10.8 \%$ for males and females, respectively).

\section{Diet composition and overlap}

A total of 9820 prey items were found in 938 stomachs of Great Cormorants assigned to subspecies (289 stomachs being empty): 9784 prey items belonged to 42 fish species (13 coastal or brackish fish species representing only $5.8 \%$ of the total number of prey, and 29 freshwater fish species representing $94.2 \%$ of the total number of prey), 30 fish prey items were not identified and six items were Red Swamp Crayfish Procambarus clarkii. In order of decreasing mean relative abundance, the most captured fish species were Roach Rutilus rutilus, Common Bream Abramis brama and Silver Bream Blicca bjoerkna (grouped together due to the difficulty of identifying juveniles of these two species), Eurasian Perch Perca fluviatilis and Bleak Alburnus alburnus (Appendix 1). They represented 69.2\% of the total number of fish captured. Other fish species did not exceed $5 \%$ each in the diet of Great Cormorants. Fish species differed markedly in their relative abundance between sites, e.g. from $3.2 \%$ to $60.9 \%$ for Roach and from $1.7 \%$ to $39.4 \%$ for bream (Appendix 1). Diet overlap was generally very high between Great Cormorant groups within sites (Table 2). Most values of diet overlap ranged from 0.726 to 0.994 , but some lower values were found, mainly in Vendée.

\section{Prey size selection}

Before comparing prey size between Great Cormorant groups, we verified that possible differences in the length of fish consumed by bird groups were not caused by a few birds in a group having eaten many small fish. To test this, three classes of fish abundance were defined (1-10, 11-20 and > 20 fish per bird). The number of fish consumed did not vary between bird groups at each separate site (Pearson chi-squared test, $P>0.05$ ), except in Morbihan, where the proportion of females of $P$. c. sinensis having captured more than 20 fish was statistically higher than that in the other bird groups (Pearson chi-squared test, $P<0.02$ ). Therefore, in the case of Morbihan, caution is needed when interpreting results of between-bird group comparisons of prey size.

The range of mean values of body length of the dominant fish species varied widely between sites (e.g. 72.4-130.1 mm for bream, 78.0-172.4 mm for Roach, 66.8-93.8 mm for Eurasian Perch) and to a lesser degree for small fish species such as Bleak (60.1-79.3 mm, 
Fonteneau et al. - 2009 - Relationships between bird morphology and prey selection in two sympatric Great Cormorant Phalacrocorax carbo subspecies during winter.

Table 3). When prey size selection was found within sites, results were only partially in accordance with the gradient of the morphology of Great Cormorant groups (post-hoc pairwise comparisons in one-way ANOVAs presented in Table 3). Indeed, larger birds consumed larger fish, but significant differences were not found every time between each bird group. For example, the size of Roach consumed by Great Cormorants in Dordogne arranged along the gradient: males of $P$. c . sinensis > (females of $P$. c c carbo $=$ females of P. c. sinensis). In three cases (bream in Ille-et-Vilaine and Sarthe, and Roach in Mayenne), the selection of fish size did not conform to the morphological gradient of Great Cormorants, as females consumed larger fish than males. Regarding analyses of the dominant fish species, prey size selection was found in a majority of sites for bream (six of a total of nine), then four of a total of nine sites for Roach and one of a total of four sites for Bleak and Eurasian Perch (Table 3).

\section{Discussion}

\section{Subspecies and sexual size dimorphism}

Based on a large sample of Great Cormorants $(n=1227)$, we found that males exceeded females in all structural size variables in both subspecies, generally in the range of values already published (Cramp \& Simmons 1977, Koffijberg \& van Eerden 1995, Newson et al. 2004 for P. c. sinensis, and Newson et al. 2004 for P. c. carbo). The body mass of the P. c. sinensis studied (adjusted for stomach content) was similar to that reported in The Netherlands (Koffijberg \& van Eerden 1995). Conversely, it was much lower for the P. c. carbo we studied (2648 and $2261 \mathrm{~g}$ for males and females, respectively; Table 1) compared to that found for wintering P. c. carbo in England and Wales (3019 and $2419 \mathrm{~g}$ for males and females, respectively; Russell et al. 1996). Thus, differences in body mass between subspecies (P. c. carbo - P. c. sinensis) were reduced to 182 and $222 \mathrm{~g}$ for males and females, respectively, in inland France, as opposed to 554 and $380 \mathrm{~g}$, respectively, expected from English P. c. carbo. Fonteneau and Marion (2009) have already shown that, whatever their age, $P$. c c carbo individuals wintering in inland France have lower body mass $-12 \%$ for males and $-18 \%$ for females) than those wintering near the marine coast. Despite this decrease in body mass of $P$. c. carbo in inland areas, we have shown a gradient of structural size and body mass between the four bird groups (males of $P$. c c carbo $>$ males of 
Fonteneau et al. - 2009 - Relationships between bird morphology and prey selection in two sympatric Great Cormorant Phalacrocorax carbo subspecies during winter.

P. c. sinensis $>$ females of $P$. c. carbo $>$ females of $P$. c . sinensis). Several non-exclusive hypotheses can be proposed to explain why P. c. carbo has low body mass in inland areas: (1) lighter individuals (i.e. more similar to $P$. c c sinensis) winter preferentially in inland waters as they are better adapted to these environments; (2) smaller birds of the same subspecies are rejected from the coast as they may be dominated by conspecifics (Fonteneau \& Marion 2009); and (3) such birds have difficulty in coping with adverse environmental conditions on the coast. Interestingly, males of $P$. c c carbo wintering in inland wetlands were more numerous $(62.1 \%)$ than females, despite their heavier body mass. Finally, differences in morphology of the Great Cormorants studied here were more marked between sexes (4.2$20.9 \%)$ than differences between subspecies (1.0-10.8\%).

\section{Comparison of diet between Great Cormorant groups}

As shown elsewhere (Kirby et al. 1996, Leopold et al. 1998), diet analyses confirmed that Great Cormorants feed on a wide variety of fish species. However, the diet was mainly composed of a few dominant prey species at the site level, especially cyprinids, which are very common in such freshwater aquatic systems (Keith \& Allardi 2001). Diet overlap was high in most cases, except in Vendée. At this site, both inland marshes and brackish areas are available for foraging, and the diet was composed of fish species from both habitats (Appendix 1). In this context, the two subspecies might focus on their traditional habitats (see Marion 1994, 1995) and probably on their usual prey species. This was not the case in the common inland feeding areas in the other sites where P. c. carbo were constrained to feed on freshwater prey species (Appendix 1). Curiously, in Vendée there was a larger segregation in diet overlap between sexes in $P$. c . sinensis $(\mathrm{Ov}=0.241$, the lowest value observed in the study), for which we have no explanation. It is therefore interesting to note that generally Great Cormorants of the marine subspecies, which use specific foraging techniques adapted to catch pelagic / benthic prey fish during most of their life stages (Grémillet et al. 1998), are able during the wintering period to capture the same prey species as birds of the inland subspecies, considered a priori to be more adapted to exploiting shallow inland aquatic environments.

There were few general patterns in food partitioning. Prey size selection was site-specific: generally males selected larger fish than females (see also Koffijberg \& van Eerden 1995 for P. c. sinensis; Campo et al. 1993, Kato et al. 1996 and Casaux et al. 2001 for other cormorant species) and differences between subspecies were less common than between sexes (Table 3 ). 
Fonteneau et al. - 2009 - Relationships between bird morphology and prey selection in two sympatric Great Cormorant Phalacrocorax carbo subspecies during winter.

This result is in accord with the lower difference in body size between subspecies compared to that between sexes. This is reinforced in our study area by the fact that Great Cormorants of the P. c. carbo subspecies wintering in inland areas were smaller than those on the coast. The variability in food partitioning across sites may reflect differences in the availability of various size-class structures of prey species between sites, although we do not have the data to test this directly. It is obvious that additional investigations are required to analyse food partitioning of Great Cormorants of differing body size with respect to detailed data on fish stocks in feeding areas. Caution is also needed in our work when considering size-selection among prey species, because the number of sites used for studying prey size was sometimes too limited for some species (e.g. Barbel Barbus barbus, Black Bullhead, Pumpkinseed Lepomis gibbosus and Rudd Scardinius erythrophthalmus). For Bleak, no difference in the size of individuals was found between Great Cormorant sexes in the two subspecies, probably because it is a small-sized fish species. The prey size selection by Great Cormorants observed among the dominant fish species (bream, Eurasian Perch and Roach) might be related to their body shape, as we found more cases of prey size-selection in bream (laterally flattened body) than in Roach (fusiform). Several authors (Koffijberg \& van Eerden 1995, Veldkamp 1995) have suggested that bream would be harder to swallow for Great Cormorants compared to more elongated fish species. This may be true given the results of the present study, even if mean body size values of bream in the diet of Great Cormorants were not very large $(\leq 130$ $\mathrm{mm})$.

Because the Great Cormorant is an opportunist predator, one might consider that the dominance of a fish species in the diet should reflect the importance of this prey species in the feeding areas. According to Pianka's (1974) hypothesis (see also Bolnick \& Doebeli 2003), a high diet overlap is expected when resources are abundant. In this context, one would predict that competition between different Great Cormorant groups for consumption of a dominant fish species should be limited in common feeding areas. However, in the present study, prey size-selection (between Great Cormorant groups) was found for all dominant fish species at some sites. Thus, food partitioning between sympatric Great Cormorants involved additional factors, such as bird morphology-related mechanisms, rather than fish availability alone.

\section{Sex morphology-related mechanisms in prey selection}

Koffijberg and van Eerden (1995) suggested that P. c. sinensis males with a larger bill should have a better handling performance for some fish species, and illustrated this with a 
Fonteneau et al. - 2009 - Relationships between bird morphology and prey selection in two sympatric Great Cormorant Phalacrocorax carbo subspecies during winter.

powerful fish, the European Eel Anguilla anguilla. In the present study, the dominant species in the diet of Great Cormorants were supposedly easy prey to handle and bill dimensions could not apparently directly explain the difference in the size of fish captured. However, we cannot exclude the fact that the thin bill of females makes catching and / or swallowing small fish more efficient than large fish.

Great Cormorants are foot-propelled divers and, as for other seabirds or mammals showing a sexual size dimorphism, the diving depth is strongly influenced by body mass (Cooper 1986, Le Boeuf et al. 1993, Lewis et al. 2006). Not surprisingly, in several marine cormorant species, males, which are heavier than females, were found to dive deeper and for longer durations than females (Watanuki et al. 1996, Kato et al. 1999, 2000, Cook et al. 2007), suggesting vertical niche segregation. This leads to the consumption of different prey species: males feed mainly on benthic fish, whereas females catch more pelagic fish (Ishikawa \& Watanuki 2002, Anderson et al. 2004). In the present study, no real segregation in diving depth could be expected because the water depth in inland feeding sites rarely exceeded $5 \mathrm{~m}$. This may partly explain the high diet overlap found in the Great Cormorant groups. In the inland aquatic environment, differences in swimming performance could reflect differences in the ability to catch large fish. Because sustained and 'burst' swimming speeds of fish are related to fish length (Sambilay 1990, Froese \& Pauly 2007), large fish could be much more difficult to catch than small fish, and larger Great Cormorants (i.e. males), which swim faster than females, might have an advantage (Ropert-Coudert et al. 2006, Cook et al. 2008). Lastly, Great Cormorants have a partially wettable plumage (Grémillet et al. 2005), which leads to poor insulation and large thermoregulatory costs when fishing (Grémillet \& Wilson 1999, Grémillet et al. 2001). Grémillet and Wilson (1999) found that size dimorphism in the Great Cormorant plays an important role in energetic needs and thermoregulatory costs, and can therefore explain differences in fishing activity and efficiency. Although these studies concerned Nordic areas, these factors might be important in France during severe winters, but winters were relatively mild during our study period.

\section{Implications of niche overlap on the maintainance of Great Cormorant subspecies}

Historically, European Great Cormorant subspecies, which probably differentiated in the Pleistocene (Marion \& Le Gentil 2006), represented ecological adaptation to distinct habitats (marine vs. inland waters). These habitat preferences persisted, even in winter, until the beginning of the 1980s (Marion 1983), when the two subspecies progressively overlapped 
Fonteneau et al. - 2009 - Relationships between bird morphology and prey selection in two sympatric Great Cormorant Phalacrocorax carbo subspecies during winter.

during winter in Western France (Marion 1995), generating mixed inland colonies in this area (Marion 1983, Marion \& Le Gentil 2006). A similar pattern was reported in the UK (Goostrey et al. 1998, Winney et al. 2001, Newson et al. 2004). The present study showed that wintering P. c. carbo occurs on inland waters across most of France, and that there is a high degree of diet overlap between the two subspecies. P. c. carbo can thus be viewed as an efficient generalist forager in both freshwater and marine habitats, and can apparently occupy more or less the same niche as $P$. c. sinensis during the nonbreeding period. In this recent contact area, ecological boundaries between subspecies are probably less clear now than in the past.

All of the above points raise the question of whether or not the two / three subspecies model is indeed applicable in Europe. A crucial stage for the maintenance of subspecies is the breeding season, during which the contact area of the two subspecies is still restricted to Western France (Loire Atlantique and Normandy), in contrast to the large common wintering area. Moreover, at the European scale, there are only two other small breeding contact areas located in Eastern UK and Southern Norway (Marion \& Le Gentil 2006). Mixed colonies are still not common or widespread when considering the world population of the two subspecies (Western Europe, Iceland, Greenland, up to North America for P. c. carbo, Europe and Asia for P. c. sinensis). Moreover, the two subspecies cohabit in mixed colonies, and hybridization concerns only a small proportion of breeders (J. Le Gentil \& L. Marion unpubl. data). Also, P. c. carbo would be less well-adapted than P. c. sinensis to inland wetlands during breeding (lower breeding success; J. Le Gentil \& L. Marion unpubl. data), and during winter mainly the lightest $P$. c. carbo individuals (Fonteneau \& Marion 2009, and the present study), more similar to the $P$. c. sinensis birds, are wintering in inland areas. In the future, it would be important to study changes in the distribution and habits of Great Cormorant subspecies in the two other European contact areas (the UK, where P. c. carbo and P. c. sinensis also meet, and south of Norway, where P. c. sinensis bred recently in the traditional area of P. c. carbo and P. c. norvegicus), to see whether the morphology of $P$. c. carbo individuals wintering on the coast and in inland areas differed, as found in France. 
Fonteneau et al. - 2009 - Relationships between bird morphology and prey selection in two sympatric Great Cormorant Phalacrocorax carbo subspecies during winter.

\section{Acknowledgements}

We are grateful to ONEMA, ONCFS, the Fédérations Départementales de Chasse, the Fédérations Départementales de Pêche and the Syndicat Mixte des Marais de la Basse Vallée de la Vie et du Ligneron, who provided a large sample of Great Cormorants shot under licence during the winter in France. We also thank the Directions Départementales de l'Agriculture et de la Forêt, who helped us with the legal transport licence of shot birds and A. Nys, a native English speaker for linguistic improvements. Lastly, we thank A. Butet, T.R. Cook, R. Phillips and two anonymous referees who provided constructive comments on a previous draft. This study was supported by a grant from SESLG.

\section{References}

Anderson, C.D., Roby, D.D. \& Collis, K. 2004. Foraging patterns of male and female Doublecrested Cormorants nesting in the Columbia River estuary. Can. J. Zool. 82: 541-554.

Bolnick, D.I. \& Doebeli, M. 2003. Sexual dimorphism and adaptive speciation: two sides of the same ecological coin. Evolution 57: 2433-2449.

Campo, J.J., Thompson, B.G., Barron, J.C., Telfair, R.C., Durocher, P. \& Gutreuter, S. 1993. Diet of Double-crested Cormorants wintering in Texas. J. Field Ornithol. 64: 135-144.

Carss, D.N. (ed.) 2003. Reducing the conflict between Cormorants and fisheries on a PanEuropean Scale. Final Report. Banchory: Centre for Ecology and Hydrology.

Casaux, R., Favero, M., Silva, P. \& Baroni, A. 2001. Sex differences in diving depths and diet of Antarctic Shags at the South Shetland Islands. J. Field Ornithol. 72: 22-29.

Chesson, P. \& Huntly, N. 1997. The roles of harsh and fluctuating conditions in the dynamics of ecological communities. Am. Nat. 150: 519-553.

Cook, T.R., Cherel, Y., Bost, C.-A. \& Tremblay, Y. 2007. Chick-rearing Crozet shags (Phalacrocorax melanogenis) display sex-specific foraging behaviour. Antarc. Sci. 19: 55-63.

Cook, T.R., Bailleul, F., Lescroe“ 1, A., Tremblay, Y. \& Bost, C.-A. 2008. Crossing the frontier: vertical transit rates of deep diving cormorants reveal depth zone of neutral buoyancy. Mar. Biol. 154: 383-391.

Cooper, J. 1986. Diving patterns of cormorants Phalacrocoracidae. Ibis 128: 562-570. 
Fonteneau et al. - 2009 - Relationships between bird morphology and prey selection in two sympatric Great Cormorant Phalacrocorax carbo subspecies during winter.

Cramp, S. \& Simmons, K.E.L. (eds) 1977. The Birds of the Western Palearctic, Vol. 1. Oxford: Oxford University Press.

van Dam, C. \& Asbirk, S. (eds) 1997. Cormorants and Human Interests. Proceedings of the Workshop towards an International Conservation and Management Plan for the Great Cormorant (Phalacrocorax carbo). Wageningen: IKC/RIZA/ NFNA.

van Eerden, M.R. \& Gregersen, J. 1995. Long-term changes in the northwest European population of Cormorants Phalacrocorax carbo sinensis. Ardea 83: 61-79.

van Eerden, M.R., Koffijberg, K. \& Platteeuw, M. (eds) 1995. Riding on the crest of the wave: possibilities and limitations for a thriving population of migratory Cormorants Phalacrocorax carbo in man-dominated wetlands. Ardea 83: 1-138.

Fonteneau, F. \& Marion, L. 2009. Characteristics of the distribution of the two European Great Cormorant subspecies in France, a sympatric wintering area. Proceedings of the $7^{\text {th }}$ Wetland International Cormorant Research Group Meeting. Lelystad: RIZA (in press).

Froese, R. \& Pauly, D. 2007. FishBase, Available at: http:// www.fishbase.org/home.htm [accessed 8 September 2008].

Garcia, J.T. \& Arroyo, G.E. 2005. Food-niche differentiation in sympatric Hen Circus cyaneus and Montagu's Harriers Circus pygargus. Ibis 147: 144-154.

Gonza'lez-Solı's, J., Croxall, J.P. \& Wood, A.G. 2000. Sexual dimorphism and sexual segregation in foraging strategies of Northern Giant Petrels, Macronectes halli, during incubation. Oikos 90: 390-398.

Goss-Custard, J.D. \& Durell, S.E.A.Le V.dit 1983. Individual and age-differences in the feeding ecology of Oystercatchers Haematopus ostralegus wintering on the Exe Estuary, Devon. Ibis 125: 155-171.

Goostrey, A., Carss, D.N., Noble, L.R. \& Piertney, S.B. 1998. Population introgression and differentiation in the Great Cormorant Phalacrocorax carbo in Europe. Mol. Ecol. 7: 329-338.

Grémillet, D. \& Wilson, R.P. 1999. A life in the fast lane: energetics and foraging strategies of the Great Cormorant. Behav. Ecol. 10: 516-524.

Grémillet, D., Argentin, G., Schulte, B. \& Culik, B.M. 1998. Flexible foraging techniques in breeding Cormorants Phalacrocorax carbo and Shags Phalacrocorax aristotelis: benthic or pelagic feeding? Ibis 140: 113-119. 
Fonteneau et al. - 2009 - Relationships between bird morphology and prey selection in two sympatric Great Cormorant Phalacrocorax carbo subspecies during winter.

Grémillet, D., Wanless, S., Carss, D.N., Linton, D., Harris, M.P., Speakman, J.R. \& Le Maho, Y. 2001. Foraging energetics of arctic cormorants and the evolution of diving birds. Ecol. Let. 4: 180-184.

Grémillet, D., Chauvin, C., Wilson, R.P., Le Maho, Y. \& Wanless, S. 2005. Unusual feather structure allows partial plumage wettability in diving Great Cormorants Phalacrocorax carbo. J. Avian Biol. 36: 57-63.

Hedrick, A.V. \& Temeles, E.J. 1989. The evolution of sexual dimorphism in animals: hypotheses and tests. Trends Ecol. Evol. 4: 136-138.

del Hoyo, J., Elliott, A. \& Sargatal, J. (eds) 1992. Handbook of the Birds of the World, Vol. 1. Barcelona: Lynx Edicions.

Ishikawa, K. \& Watanuki, Y. 2002. Sex and individual differences in foraging behaviour of Japanese Cormorants in years of different prey availability. J. Ethol. 20: 49-54.

Kato, A., Nishiumi, I. \& Naito, Y. 1996. Sexual differences in the diet of King Cormorants at Macquarie Island. Polar Biol. 16: 75-77.

Kato, A., Watanuki, Y., Shaughnessy, P., Le Maho, Y. \& Naito, Y. 1999. Intersexual differences in the diving behaviour of foraging subantarctic Cormorant (Phalacrocorax albiventer) and Japanese Cormorant (P. filamentosus). C. R. Acad. Sci. III 322: 557-562.

Kato, A., Watanuki, Y., Nishiumi, I., Kuroki, M., Shaughnessy, P. \& Naito, Y. 2000. Variation in foraging and parental behavior of King Cormorants. Auk 117: 718-730.

Keith, P. \& Allardi, J. (eds) 2001. Atlas des Poissons d'Eau Douce de France. Collection Patrimoines Naturels 47. Paris: MNHN/EGB/SPN.

Keller, T.M., Carss, D.N., Helbig, A.J. \& Flade, M. (eds) 2003. Cormorants: Ecology and Management at the Start of the 21st Century. Proceedings of the 5th International Conference on Cormorants. Vogelwelt 124 (Suppl.): 1-402.

Kirby, J.S., Holmes, J.S. \& Sellers, R.M. 1996. Cormorant Phalacrocorax carbo as fish predators: an appraisal of their conservation and management in Great Britain. Biol. Conserv. 75: 191-199.

Koffijberg, K. \& van Eerden, M.E. 1995. Sexual dimorphism in the Cormorant Phalacrocorax carbo sinensis: possible implications for differences in structural size. Ardea 83: 37-46. 
Fonteneau et al. - 2009 - Relationships between bird morphology and prey selection in two sympatric Great Cormorant Phalacrocorax carbo subspecies during winter.

Le Boeuf, B.J., Crocker, D.E., Blackwell, S.B., Morris, P.A. \& Thorson, P.H. 1993. Sex differences in diving and foraging behaviour of Northern Elephant Seals. Symp. Zool. Soc. Lond. 166: 149-178.

Leopold, M.F., van Damme, C.J.G. \& van der Beer, H.W. 1998. Diet of cormorants and the impact of cormorant predation on juvenile Flatfish in the Dutch Wadden Sea. J. Sea Res. 40: 93-107.

Lewis, R., O’Connell, R.C., Lewis, M., Campagna, C. \& Rus Hoelzel, A. 2006. Sex-specific foraging strategies and resource partitioning in the Southern Elephant Seal (Mirounga leonina). Proc. R. Soc. Lond. B 273: 2901-2907.

Marion, L. 1983. Problèmes biogéographiques, écologiques et taxonomiques posés par le Grand Cormoran Phalacrocorax carbo. Rev. Ecol. (Terre \& Vie) 38: 65-99.

Marion, L. 1989. Territorial feeding and colonial breeding are not necessarily mutually exclusive spatial occupation systems: the case of the Grey Heron (Ardea cinerea). J. Anim. Ecol. 58: 693-710.

Marion, L. 1994. Evolution numérique et préférences écologiques des Grands Cormorans Phalacrocorax carbo hivernant en France. Alauda 62: 13-26.

Marion, L. 1995. Where two subspecies meet: origin, habitat choice and niche segregation of Cormorant Phalacrocorax c. carbo and P. c. sinensis in the common wintering area (France), in relation to breeding isolation in Europe. Ardea 83: 103-114.

Marion, L. 1997. Le Grand Cormoran en Europe: dynamique des populations et impacts. In Clergeau, P. (ed.). Oiseaux à Risques: 133-178. Paris: INRA Editions.

Marion, L. 2007. Recensement National des Grands Cormorans hivernant en France durant l'Hiver 2006-07. Rennes: Ministère de l'Ecologie du Développement et de l'Aménagement durables, MNHN, Université de Rennes et SESLG.

Marion, L. \& Le Gentil, J. 2006. Ecological segregation and population structuring of the Cormorant Phalacrocorax carbo in Europe, in relation to the recent introgression of continental and marine subspecies. Evol. Ecol. 20: 193-216.

Marion, L. \& Parz-Gollner, R. 2009. Pan-European mid-winter census of wintering Great Cormorant in January 2003. Proceedings of the 7th Wetland international Cormorant Research Group Meeting. Lelystad: RIZA.

Marti, C.D., Steenhof, K., Kochert, M.N. \& Marks, J.S. 1993. Community trophic structure the role of diet, body size, and activity time in vertebrate predators. Oikos 67: 6-18. 
Fonteneau et al. - 2009 - Relationships between bird morphology and prey selection in two sympatric Great Cormorant Phalacrocorax carbo subspecies during winter.

Newson, S.E., Hughes, B., Russell, I.C., Ekins, G.R. \& Sellers, R.M. 2004. Sub-specific differentiation and distribution of Great Cormorants Phalacrocorax carbo in Europe. Ardea 92: 3-10.

Pianka, E.R. 1974. Niche overlap and diffuse competition. Proc. Natl Acad. Sci. U.S.A. 71: 2141-2145.

Ropert-Coudert, Y., Grémillet, D. \& Kato, A. 2006. Swim speeds of free-ranging Great Cormorants. Mar. Biol. 149: 415-422.

Russell, I.C., Dare, P.J., Eaton, D.R. \& Armstrong, J.D. 1996. Assessment of the problem of fish-eating birds in Inland fisheries in England and Wales. Lowestoft: Ministry of Agriculture, Fisheries and Food, Directorate of Fisheries Research.

Sambilay, V.C. 1990. Interrelationships between swimming speed, caudal fin aspect ratio and body length. Fishbyte 8: 16-20.

Shaffer, S.A., Weimerskirch, H. \& Costa, D.P. 2001. Functional significance of sexual dimorphism in Wandering Albatrosses, Diomedea exulans. Funct. Ecol. 15: 203-210.

Shine, R. 1989. Ecological causes for the evolution of sexual dimorphism: a review of the evidence. Q. Rev. Biol. 64: 419-461.

Slagsvold, T. \& Sonerud, G. 2007. Prey size and ingestion rate in raptors: importance for sex roles and reversed sexual size dimorphism. J. Avian Biol. 38: 650-661.

Slatkin, M. 1984. Ecological causes of sexual dimorphism. Evolution 38: 622-630.

Suter, W. 1997. Roach rules: shoaling fish are a constant factor in the diet of Cormorants Phalacrocorax carbo in Switzerland. Ardea 83: 9-27.

Veldkamp, R. 1995. Diet of Cormorants Phalacrocorax carbo sinensis at Wanneperveen, The Netherlands, with special reference to Bream Abramis brama. Ardea 83: 143-155.

Wanless, S., Harris, M.P. \& Morris, J.A. 1995. Factors affecting daily activity budgets of South Georgian shags during chick rearing at Bird Island, South Georgia. Condor 97: $550-558$.

Watanuki, Y., Kato, A. \& Naito, Y. 1996. Diving performance of male and female Japanese Cormorants. Can. J. Zool. 74: 1098-1109.

Weimerskirch, H., Salamolard, M., Sarrazin, F. \& Jouventin, F. 1993. Foraging strategy of Wandering Albatrosses through the breeding season: a study using satellite telemetry. Auk 110: 325-342. 
Fonteneau et al. - 2009 - Relationships between bird morphology and prey selection in two sympatric Great Cormorant Phalacrocorax carbo subspecies during winter.

Weimerskirch, H., Le Corre, M., Ropert-Coudert, Y., Kato, A. \& Marsac, F. 2006. Sexspecific foraging behaviour in a seabird with reversed sexual dimorphism: the Redfooted Booby. Oecologia 146: 681-691.

Winney, B.J., Litton, C.D., Parkin, D.T. \& Feare, C.J. 2001. The subspecific origin of the inland breeding colonies of the Cormorant Phalacrocorax carbo in Britain. Heredity 86: 45-53.

Ydenberg, R.C. \& Forbes, L.S. 1991. The survival-reproduction selection equilibrium and reversed size dimorphism in raptors. Oikos 60: 115-120.

Zalewski, A. 2007. Does size dimorphism reduce competition between sexes? The diet of male and female Pine Martens at local and wider geographical scales. Acta Theriol. 52: $237-250$. 
Fonteneau et al. - 2009 - Relationships between bird morphology and prey selection in two sympatric Great Cormorant Phalacrocorax carbo subspecies during winter.

Figure 1. French sites (administrative districts) where Great Cormorants Phalacrocorax carbo shot under licence $(n=1227)$ have been collected during the winters $2001 / 2002$ to $2006 / 2007$, with major sites ( $\geq 20$ birds assigned to subspecies) in dark grey and other sites in light grey. Proportions of birds identified to subspecies ( $P$. c . carbo in black and P. c. sinensis in grey) using the gular pouch angle criteria (see the text for details) are reported for major sites. The list of sites is given in which major sites are in bold and sites where the P. c. carbo subspecies is absent are indicated with an asterisk.

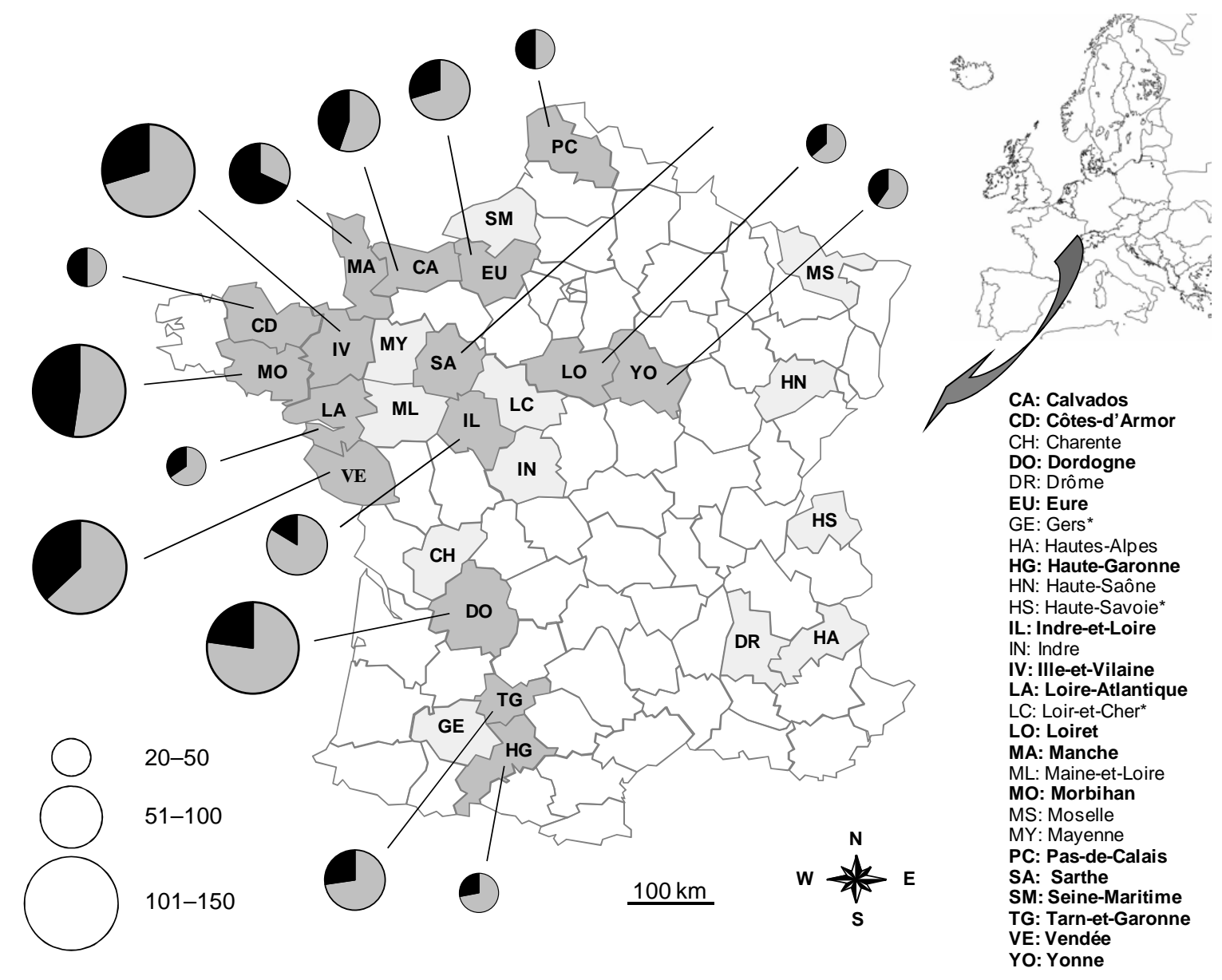


Fonteneau et al. - 2009 - Relationships between bird morphology and prey selection in two sympatric Great Cormorant Phalacrocorax carbo subspecies during winter.

Table 1. Morphological measurements of Great Cormorants Phalacrocorax carbo collected in France during the winters of $2001 / 2002$ to $2006 / 2007(\mathrm{n}=1227)$ according to subspecies $(P$. c. carbo and P. c. sinensis) and sex.

\begin{tabular}{|c|c|c|c|c|c|c|c|}
\hline \multirow[t]{2}{*}{ Subspecies } & \multirow[t]{2}{*}{ Biometrics } & \multicolumn{3}{|c|}{ Males } & \multicolumn{3}{|c|}{ Females } \\
\hline & & Mean \pm sd & Range & Sample size & Mean $\pm s d$ & Range & Sample size \\
\hline \multicolumn{8}{|l|}{ P. c. carbo } \\
\hline & Body mass & $2647.6 \pm 329.0$ & $1594-3625$ & 261 & $2260.7 \pm 265.3$ & $1458-3045$ & 159 \\
\hline & Wing-length & $355.6 \pm 7.7$ & $336-371$ & 261 & $337.3 \pm 8.3$ & $316-368$ & 159 \\
\hline & Tarsus-length & $63.8 \pm 2.9$ & $54.0-73.0$ & 261 & $61.2 \pm 2.6$ & $54.5-69.5$ & 159 \\
\hline & Bill-length & $71.0 \pm 4.0$ & $61.0-82.0$ & 261 & $64.8 \pm 3.6$ & $57.0-74.0$ & 159 \\
\hline & Bill-depth & $23.3 \pm 1.3$ & $19.6-27.2$ & 261 & $21.2 \pm 1.3$ & $17.4-24.6$ & 159 \\
\hline & Bill-width & $18.6 \pm 1.0$ & $15.6-22.5$ & 261 & $17.5 \pm 1.0$ & $15.2-21.3$ & 159 \\
\hline \multicolumn{8}{|l|}{ P. c. sinensis } \\
\hline & Body mass & $2465.5 \pm 245.0$ & $1780-3448$ & 382 & $2039.1 \pm 214.6$ & $1329-2643$ & 425 \\
\hline & Wing-length & $352.1 \pm 8.9$ & $328-378$ & 382 & $332.5 \pm 7.4$ & $310-369$ & 425 \\
\hline & Tarsus-length & $62.0 \pm 2.9$ & $55.0-69.0$ & 382 & $59.1 \pm 2.4$ & $53.0-66.5$ & 425 \\
\hline & Bill-length & $67.9 \pm 3.2$ & $59.0-78.0$ & 382 & $61.2 \pm 2.9$ & $53.0-71.0$ & 425 \\
\hline & Bill-depth & $22.6 \pm 1.1$ & $15.2-21.8$ & 382 & $20.3 \pm 0.9$ & $17.6-27.0$ & 425 \\
\hline & Bill-width & $18.0 \pm 1.0$ & $17.9-26.3$ & 382 & $16.7 \pm 1.0$ & $13.4-20.9$ & 425 \\
\hline
\end{tabular}

All measurements in mm except the body mass in $\mathrm{g}$.

Table 2. Trophic overlap indices (Pianka 1974) between Great Cormorant Phalacrocorax carbo groups (based on sex and subspecies) collected in various French sites during the winters of $2001 /$ 2002 to 2006 / 2007. Sample sizes (number of birds and number of fish) are reported in Appendix 1.

\begin{tabular}{|c|c|c|c|c|c|c|}
\hline Sites & $\begin{array}{l}\text { †P. c. carbo/ } \\
\text { ○P. c. carbo }\end{array}$ & $\begin{array}{l}\text { PP.c. sinensis/ } \\
\text { †P.c. sinensis }\end{array}$ & $\begin{array}{l}P \text { P. c. carbo/ } \\
P . c . \text { sinensis }\end{array}$ & $\begin{array}{l}\text { q P. c. carbo/ } \\
\uparrow P . c . \text { sinensis }\end{array}$ & $\begin{array}{l}\gamma P . \boldsymbol{c} . \text { carbo/ } \\
\nmid P . c . \text { sinensis }\end{array}$ & $\begin{array}{l}+P . c . \text { carbo/ } \\
\text { P } \boldsymbol{P} \text { c. sinensis }\end{array}$ \\
\hline Dordogne & - & 0.790 & 0.868 & - & 0.521 & - \\
\hline Ille-et-Vilaine & 0.931 & 0.920 & 0.918 & 0.937 & 0.994 & 0.991 \\
\hline Indre-et-Loire & - & 0.889 & - & - & - & - \\
\hline Morbihan & 0.861 & 0.933 & 0.834 & 0.952 & 0.836 & 0.874 \\
\hline Vendée & 0.798 & 0.241 & 0.572 & 0.726 & 0.776 & 0.614 \\
\hline
\end{tabular}

- denotes missing value 
Fonteneau et al. - 2009 - Relationships between bird morphology and prey selection in two sympatric Great Cormorant Phalacrocorax carbo subspecies during winter.

Table 3. Comparison of body length (in $\mathrm{mm}$ ) of fish species consumed by different subspecies and sexes of Great Cormorant Phalacrocorax carbo collected in each French site during the winters of $2001 / 2002$ to $2006 / 2007$.

\begin{tabular}{|c|c|c|c|c|c|c|}
\hline Fish species & Sites & Mean \pm sd & $n$ & $d f$ & $F$ or $t$ & Pairwise comparisons \\
\hline Barbel & Loiret & $84.1 \pm 43.2$ & 184 & 2 & $3.56^{*}$ & $\mathrm{C}^{\mathrm{ab}}, \mathrm{S}^{\mathrm{a}}, q \mathrm{~S}^{\mathrm{b}}$ \\
\hline \multirow[t]{4}{*}{ Bleak } & Dordogne & $61.9 \pm 25.5$ & 126 & 1 & 0.02 & $q \mathrm{C}, q \mathrm{~S}$ \\
\hline & Indre-et-Loire & $60.1 \pm 17.2$ & 195 & 1 & $3.76^{* * *}$ & $\mathrm{~S}^{\mathrm{a}},+\mathrm{S}^{\mathrm{b}}$ \\
\hline & Morbihan & $79.3 \pm 19.9$ & 112 & 2 & 0.14 & $\zeta \mathrm{C},+\mathrm{C},+\mathrm{S}$ \\
\hline & Tarn-et-Garonne & $64.8 \pm 21.1$ & 106 & 1 & -0.86 & $\delta \mathrm{S},+\mathrm{S}$ \\
\hline Black Bulhead & Sarthe & $111.2 \pm 37.5$ & 91 & 2 & $15.57 * * *$ & $\mathrm{C}^{\mathrm{b}}, \mathrm{S}^{\mathrm{a}},+\mathrm{S}^{\mathrm{a}}$ \\
\hline \multirow[t]{9}{*}{ Bream } & Dordogne & $130.1 \pm 55.3$ & 53 & 1 & 0.12 & $\precsim \mathrm{S}, q \mathrm{~S}$ \\
\hline & Eure & $99.2 \pm 39.3$ & 226 & 3 & 1.87 & 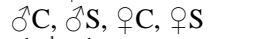 \\
\hline & Ille-et-Vilaine & $91.5 \pm 44.4$ & 375 & 3 & $36.75^{* * *}$ & $\mathbf{C}^{\mathrm{b}}, \mathbf{S}^{\mathrm{a}},+\mathbf{C}^{\mathrm{a}},+\mathbf{S}^{\mathrm{c}}$ \\
\hline & Indre-et-Loire & $72.4 \pm 33.9$ & 220 & 1 & $-2.84 * *$ & $\mathbf{S}^{\mathrm{a}},+\mathrm{S}^{\mathrm{b}}$ \\
\hline & Loire-Atlantique & $74.6 \pm 50.0$ & 96 & 2 & $24.84 * * *$ & $\mathrm{~S}^{\mathrm{a}}, q \mathrm{C}^{\mathrm{b}}, q \mathrm{~S}^{\mathrm{c}}$ \\
\hline & Morbihan & $103.3 \pm 55.5$ & 159 & 3 & $7.01 * * *$ & $\mathrm{C}^{\mathrm{a}}, \widehat{S}^{\mathrm{ab}}, q \mathbf{C}^{\mathrm{c}}, q \mathbf{S}^{\mathrm{bc}}$ \\
\hline & Pas-de-Calais & $66.5 \pm 18.3$ & 89 & 1 & -0.23 & $q \mathrm{C}, q \mathrm{~S}$ \\
\hline & Sarthe & $84.8 \pm 46.4$ & 205 & 1 & $-2.30 * *$ & $\mathbf{S}^{\mathrm{b}},+\mathbf{S}^{\mathrm{a}}$ \\
\hline & Seine-Maritime & $76.3 \pm 11.3$ & 145 & 2 & $15.79 * * *$ & $\mathrm{C}^{\mathrm{a}}, \mathrm{S}^{\mathrm{b}}, q \mathrm{~S}^{\mathrm{b}}$ \\
\hline \multirow[t]{4}{*}{ Eurasian Perch } & Dordogne & $75.1 \pm 26.1$ & 319 & 2 & 0.84 & $\partial \mathrm{C},{ }^{\lambda} \mathrm{S}, q \mathrm{~S}$ \\
\hline & Ille-et-Vilaine & $93.1 \pm 32.7$ & 145 & 3 & 2.32 & ${ }^{\top} \mathrm{C}, \mathrm{S},+\mathrm{C}, q \mathrm{~S}$ \\
\hline & Morbihan & $93.8 \pm 34.2$ & 115 & 2 & $8.70^{* * *}$ & $\mathbf{C}^{\mathrm{a}},+\mathbf{C}^{\mathrm{b}},+\mathbf{S}^{\mathrm{b}}$ \\
\hline & Sarthe & $66.8 \pm 16.6$ & 199 & 1 & -1.11 & $\jmath \mathrm{S}, q \mathrm{~S}$ \\
\hline Common Dragonet & Calvados & $143.3 \pm 23.0$ & 144 & 3 & $2.85^{*}$ & $\mathbf{C}^{\mathrm{abc}}, \mathbf{S}^{\mathrm{b}},+\mathbf{C}^{\mathrm{abc}},+\mathbf{S}^{\mathrm{c}}$ \\
\hline Pumpkinseed & Dordogne & $61.1 \pm 17.9$ & 103 & 1 & $8.57 * * *$ & $\mathrm{~S}^{\mathrm{a}},+\mathrm{S}^{\mathrm{b}}$ \\
\hline \multirow[t]{9}{*}{ Roach } & Dordogne & $84.6 \pm 37.1$ & 484 & 2 & $22.46 * * *$ & $\mathrm{~S}^{\mathrm{a}},+\mathrm{C}^{\mathrm{b}}, q \mathbf{S}^{\mathrm{b}}$ \\
\hline & Eure & $89.6 \pm 28.8$ & 340 & 3 & 0.41 & ${ }^{\prime} \mathbf{C},+\mathrm{S}, q \mathrm{~S}$ \\
\hline & Ille-et-Vilaine & $83.4 \pm 33.5$ & 884 & 3 & 2.03 & 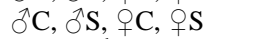 \\
\hline & Indre-et-Loire & $78.0 \pm 32.6$ & 167 & 1 & $3.03 * *$ & $\mathrm{~S}^{\mathrm{a}},+\mathrm{S}^{\mathrm{b}}$ \\
\hline & Loire-Atlantique & $95.8 \pm 30.0$ & 68 & 3 & 0.08 & ${ }^{\top} \mathrm{S}, q \mathrm{C}, q \mathrm{~S}$ \\
\hline & Manche & $164.4 \pm 97.3$ & 68 & 1 & 0.13 & $\widehat{\jmath} \mathrm{C},+\mathrm{C}$ \\
\hline & Mayenne & $88.7 \pm 20.6$ & 117 & 3 & $63.71 * * *$ & $\mathbf{S}^{\mathrm{b}},+\mathbf{C}^{\mathrm{a}},+\mathbf{S}^{\mathrm{c}}$ \\
\hline & Morbihan & $86.8 \pm 33.6$ & 484 & 3 & $14.47 * * *$ & $\partial \mathbf{C}^{\mathrm{a}}, \mathrm{S}^{\mathrm{a}},+\mathrm{C}^{\mathrm{b}},+\mathrm{S}^{\mathrm{b}}$ \\
\hline & Sarthe & $95.2 \pm 43.6$ & 160 & 2 & 2.32 & 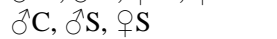 \\
\hline \multirow[t]{2}{*}{ Rudd } & Morbihan & $76.3 \pm 13.0$ & 52 & 1 & $1.81^{*}$ & $+\mathbf{C}^{\mathrm{a}},+\mathbf{S}^{\mathrm{b}}$ \\
\hline & Tarn-et-Garonne & $66.7 \pm 14.1$ & 167 & 1 & $4.64 * * *$ & $\mathrm{C}^{\mathrm{a}},+\mathrm{S}^{\mathrm{b}}$ \\
\hline Sunbleak & Ille-et-Vilaine & $36.1 \pm 7.0$ & 208 & 1 & $7.59 * * *$ & $\mathrm{C}^{\mathrm{a}},+\mathrm{S}^{\mathrm{b}}$ \\
\hline Thin-lipped Grey Mulet & Vendée & $123.3 \pm 49.6$ & 123 & 2 & 0.43 & $\widehat{J} \mathrm{~S}, q \mathrm{C}, q \mathrm{~S}$ \\
\hline
\end{tabular}

$\partial^{\lambda} \mathrm{C}=$ male of $P . c$. carbo, $+\mathrm{C}=$ female of $P$. c. carbo, $\partial^{\lambda} \mathrm{S}=$ male of $P . c$. sinensis and $\phi \mathrm{S}=$ female of $P . c$. sinensis. For each site, bird groups with the same letter are not significantly different at $P>0.05$ from pairwise comparisons following significant overall $F$-test. Letters are arranged in a decreasing order with respect to the body length of fish consumed. When the overall test is not significant, bird groups are reported without any letter.

$* P \leq 0.05, * * P \leq 0.01$, *** $P \leq 0.001$. 
Fonteneau et al. - 2009 - Relationships between bird morphology and prey selection in two sympatric Great Cormorant Phalacrocorax carbo subspecies during winter.

\section{Appendix 1}

Abundance of fish species (\%) in the diet of Great Cormorants (Phalacrocorax c. carbo and P. c. sinensis) collected in various French sites (site codes given in Fig. 1) during the winters of $2001 / 2002$ to 2006 / 2007. The total numbers of fish and birds with food items are given at the bottom of the table.

\begin{tabular}{|c|c|c|c|c|c|c|c|c|c|c|c|c|c|c|c|}
\hline \multirow[b]{2}{*}{ Species } & \multicolumn{15}{|c|}{ Sites } \\
\hline & CA & CD & DO & $\mathbf{E U}$ & IV & IL & LO & LA & MA & MO & SA & TG & VE & YO & All* \\
\hline \multicolumn{16}{|l|}{ Anguillidae } \\
\hline European Eel Anguilla Anguilla & 1.7 & - & 0.1 & 0.1 & 0.1 & - & - & - & 0.6 & 0.2 & - & - & 2.4 & - & 0.4 \\
\hline \multicolumn{16}{|l|}{ Esocidae } \\
\hline Pike Esox lucius & 0.4 & 3.7 & 0.4 & - & 0.3 & 0.3 & 1.2 & 0.6 & 2.4 & 0.8 & 0.1 & 0.2 & - & 0.7 & 0.5 \\
\hline \multicolumn{16}{|l|}{ Salmonidae } \\
\hline Rainbow Trout Salmo gairdneri & - & - & - & - & - & - & - & - & - & - & - & - & - & - & 0.2 \\
\hline \multicolumn{16}{|l|}{ Cyprinidae } \\
\hline Schneider Alburnoides bipunctatus & - & - & - & - & - & - & - & 1.4 & - & - & - & - & - & - & 0.1 \\
\hline Bleak Alburnus alburnus & 4.1 & 9.6 & 9.2 & 4.2 & 3.0 & 25.5 & 7.0 & 12.5 & - & 10.5 & 2.3 & 19.4 & 0.2 & 2.8 & 8.5 \\
\hline Barbel Barbus barbus & - & - & 1.9 & - & - & 4.8 & - & 54.6 & - & - & 0.2 & 0.9 & - & 0.7 & 2.7 \\
\hline Golfish Carassius auratus & - & - & 1.7 & - & - & - & - & - & - & - & - & - & - & - & 0.2 \\
\hline Crucian Carp Carassius gibelio & 0.8 & 2.1 & 0.6 & - & - & 0.3 & - & - & - & - & - & 5.9 & 4.0 & - & 0.7 \\
\hline Common Carp Cyprinus carpio & 2.1 & - & 1.9 & 4.5 & 0.1 & 0.3 & 4.7 & - & 6.6 & 0.7 & 4.1 & 4.2 & 1.0 & - & 1.7 \\
\hline Breams Abramis brama and Blicca bjoerkna & 1.7 & 6.4 & 4.0 & 33.5 & 20.5 & 30.1 & 39.4 & 0.3 & 6.6 & 14.9 & 25.7 & 0.2 & 1.4 & 16.7 & 17.3 \\
\hline Nase Chondrostoma nasus & - & - & 0.1 & - & - & - & - & - & - & - & 0.2 & - & - & - & $<0.1$ \\
\hline Sunbleak Leucaspius delineates & - & 1.6 & 4.7 & - & 11.4 & - & 0.4 & - & - & 1.3 & 3.8 & 0.5 & - & - & 3.4 \\
\hline Chub Leuciscus cephalus & - & - & 2.0 & 0.1 & 0.1 & 0.5 & - & 1.7 & 0.6 & 0.2 & 0.3 & - & - & 4.2 & 0.6 \\
\hline Dace Leuciscus leuciscus & - & - & 3.2 & - & - & - & - & 1.1 & - & - & - & 0.5 & - & - & 0.5 \\
\hline Roach Rutilus rutilus & 4.6 & 42.4 & 34.5 & 50.5 & 48.1 & 22.1 & 27.5 & 4.0 & 60.9 & 45.3 & 18.6 & 21.2 & 3.2 & 22.9 & 33.0 \\
\hline Rudd Scardinius erythrophtalmus & 5.0 & 3.2 & 2.3 & - & 0.4 & 0.4 & - & - & 1.8 & 5.2 & 0.2 & 30.5 & - & 11.1 & 3.2 \\
\hline Tench Tinca tinca & - & - & 0.4 & - & $0 \cdot 2$ & - & - & 0.8 & 1.2 & 0.2 & - & 5.5 & - & - & 0.5 \\
\hline Gudgeon Gobio gobio & - & - & 0.2 & 0.1 & - & 0.1 & - & 16.1 & - & - & 0.5 & 0.7 & - & 0.7 & 0.8 \\
\hline Bitterling Rhodeus sericeus & - & - & - & - & - & 0.5 & - & 0.6 & - & - & - & - & - & - & 0.1 \\
\hline Top mouth Gudgeon Pseudorasbora parva & - & - & - & - & - & - & - & - & - & - & - & - & - & - & $<0.1$ \\
\hline \multicolumn{16}{|l|}{ Cobitidae } \\
\hline Stone Loach Barbatula barbatula & - & - & - & - & - & - & - & 0.6 & - & - & - & - & - & - & $<0.1$ \\
\hline Siluridae & & & & & & & & & & & & & & & \\
\hline Wels Silurus glanis & - & - & - & - & - & - & - & 0.6 & - & - & - & - & - & - & $<0.1$ \\
\hline Ictaluridae & & & & & & & & & & & & & & & \\
\hline Black Bulhead Ameiurus melas & - & - & 0.9 & - & 2.6 & 0.5 & 17.4 & - & - & 3.3 & 10.3 & 7.7 & 5.6 & 2.1 & 3.4 \\
\hline Gadidae & & & & & & & & & & & & & & & \\
\hline Gilthead Sparus aurata & 1.7 & - & - & - & - & - & - & - & - & - & - & - & - & - & $<0.1$ \\
\hline Poeciliidae & & & & & & & & & & & & & & & \\
\hline Mosquitofish Gambusia affinis holbrooki & - & - & - & - & - & - & - & - & - & - & - & - & 1.6 & - & 0.1 \\
\hline Atherinidae & & & & & & & & & & & & & & & \\
\hline Big-scaled Sandsmelt Atherina boyeri & - & - & - & - & - & - & - & - & - & - & - & - & 41.6 & - & 2.1 \\
\hline Syngnathidae & & & & & & & & & & & & & & & \\
\hline Pipefish Syngnathus sp. & - & - & - & - & - & - & - & - & - & - & - & - & 0.2 & - & $<0.1$ \\
\hline Gasterosteidae & & & & & & & & & & & & & & & \\
\hline Three-spined Stickleback Gasterosteus aculeatus & - & - & - & - & - & - & - & - & - & - & - & - & 4.2 & - & 0.2 \\
\hline Cottidae & & & & & & & & & & & & & & & \\
\hline Bullhead Cottus gobio & 8.7 & - & - & - & - & - & - & - & - & - & - & - & - & - & 0.2 \\
\hline Agonidae & & & & & & & & & & & & & & & \\
\hline Pogge Agonus cathaphractus & 0.4 & - & - & - & - & - & - & - & - & - & - & - & - & - & $<0.1$ \\
\hline Moronidae & & & & & & & & & & & & & & & \\
\hline Bass Dicentrarchus labrax & - & - & - & - & - & - & - & - & - & - & - & - & 10.5 & - & 0.5 \\
\hline Percidae & & & & & & & & & & & & & & & \\
\hline Ruffe Gymnocephalus cernuus & - & 0.5 & 0.8 & 2.8 & 1.9 & 9.3 & 0.4 & 0.3 & 1.8 & 4.1 & 8.8 & 0.2 & - & 1.4 & 2.8 \\
\hline Eurasian Perch Perca fuviatilis & 7.5 & 27.8 & 22.6 & 3.3 & 7.9 & 4.1 & 0.4 & 1.7 & 15.1 & 11.3 & 23.5 & 0.4 & - & 29.7 & 10.4 \\
\hline Zander Stizostedion lucioperca & - & 2.7 & 0.8 & 0.6 & 0.9 & 0.6 & 1.6 & 2.3 & 0.6 & 1.2 & 1.3 & - & - & 0.7 & 0.8 \\
\hline Centrarchidae & & & & & & & & & & & & & & & \\
\hline Pumpkinseed Lepomis gibbosus & - & - & 7.4 & 0.3 & 2.5 & 0.6 & - & 0.8 & - & 0.8 & 0.1 & 1.6 & 0.2 & 6.3 & 2.1 \\
\hline Black-Bass Micropterus salmoides & - & - & 0.3 & - & - & - & - & - & - & - & - & 0.4 & - & - & 0.1 \\
\hline Sparidae & & & & & & & & & & & & & & & \\
\hline Gilthead Sparus auratus & - & - & - & - & - & - & - & - & - & - & - & - & 0.2 & - & $<0.1$ \\
\hline Mugilidae & & & & & & & & & & & & & & & \\
\hline Thin-lipped Grey Mulet Liza ramada & - & - & - & - & - & - & - & - & - & - & - & - & 20.7 & - & 1.1 \\
\hline Gobiidae & & & & & & & & & & & & & & & \\
\hline Common Goby Pomatoschistus microps & - & - & - & - & - & - & - & - & - & - & - & - & 1.4 & - & 0.1 \\
\hline Callionymidae & & & & & & & & & & & & & & & \\
\hline Common Dragonet Callionymus lyra & 59.6 & - & - & - & - & - & - & - & - & - & - & - & - & - & 1.5 \\
\hline Pleuronectidae & & & & & & & & & & & & & & & \\
\hline Flounder Platichthyus flesus & - & - & - & - & - & - & - & - & 1.8 & - & - & - & 1.6 & - & 0.1 \\
\hline Plaice Pleuronectes platessa & 1.7 & - & - & - & - & - & - & - & - & - & - & - & - & - & $<0.1$ \\
\hline Number of fish & 241 & 187 & 1414 & 674 & 1830 & 773 & 258 & 353 & 166 & 1070 & 910 & 547 & 503 & 144 & 9784 \\
\hline Number of birds with food items & 34 & 27 & 125 & 65 & 131 & 61 & 30 & 35 & 33 & 94 & 90 & 35 & 79 & 24 & 934 \\
\hline
\end{tabular}

- denotes absence of prey species. *: the sites detailed in the table plus 14 other sites with a low number of Great Cormorants $(<20$ birds with food item in each site). See the list of sites and codes on Fig. 1. 